\title{
Computer mediated communication and collaborative learning in an undergraduate distance education environment
}

\author{
Mary Graham and Helen Scarborough \\ Deakin University
}

Deakin University has, over a number of years, committed resources to the development of communication technologies in all aspects of teaching and learning. In 1996, staff in the School of Economics decided to adopt the use of computer mediated communication (CMC) in both the teaching and assessment of the first year microeconomics and macroeconomics units to distance education students.

This paper reports on the use of CMC and collaborative learning among distance education students studying first year macroeconomics. Quantitative data is based on questionnaires completed by students over two semesters and qualitative analysis on the experience of both staff and students.

Evidence suggests a positive response by students to the use of CMC in the teaching of economics using a collaborative learning approach. This supports the findings of previous studies that students' learning experiences are improved through collaborative learning.

\section{Introduction}

Distance education, as with face to face teaching, includes many organisational structures and programs based on different models of teaching and learning. Computer mediated communication (CMC) is now being used by a number of institutions as a supplement to paper-based media, audio and video recordings and the telephone, systems traditionally available to overcome the separation of teaching and learning which characterises distance education. Alternative teaching methodologies are being identified as the most appropriate way to develop new skills required by the business community and to respond to the changing educational environment. This paper examines the introduction of CMC with distance education students, by the School of Economics at Deakin University's Warrnambool campus. The emphasis of the program was to develop collaborative learning among first year 
economic students with the aim of improving student outcomes. The study examines the influence of the instructional environment on student performance and satisfaction.

\section{Why develop collaborative learning?}

Collaborative learning refers to the acquisition of knowledge, skills, or attitudes, that takes place as a result of people working together to create meaning, explore a topic, or improve skills. More formally, it emphasises the cooperative efforts between students and the generation, rather than transmission, of knowledge. Social and intellectual interaction is highlighted. It differs from other group work due to its emphasis on highly structured techniques to ensure interdependence within groups while maintaining individual accountability.

Collaborative or group learning is premised upon a learner-centred model that treats the learner as an active participant who construes knowledge from a wide range of experiences, information sources and interaction with others (Harasim 1990, Laurillard 1993). Some agreement on common goals and the pooling of individual competencies for the benefit of the group as a whole is necessary for successful collaboration.

Common features identified in the literature (Kimber 1994) are student based or student centred activities, whereby students assist each other to find answers to areas of common inquiry and solve problems by data gathering, analysis and group discussion. This can be achieved through the use of group based assignments, research projects, case studies or class paper preparation and presentations. It is the instructor's role to structure and then monitor activities to develop collaborative learning. The instructor becomes a resource and a facilitator for the learning activities of the group.

Educational research identifies peer interaction among students as a critical variable in learning and cognitive development at all levels (Harasim 1990). Sociomotional variables such as motivation, anxiety and satisfaction are claimed to benefit from working with peers. Research also shows peer interaction assists learners in understanding new concepts and provides an opportunity to commit these concepts to memory (Cohen 1984).

Kaye (1992) claims the strengths of collaborative learning through discussion and conversation include the sharing of different perspectives, the obligation to make explicit and communicate one's own knowledge 
and understandings to others and the motivational value of being a member of a healthy group. Some evaluation and/or cooperation of peer activities is a feature.

\section{CMC and collaborative learning}

The online environment, and in particular, computer conferencing is an effective medium to provide the social aspect of learning emphasised with collaborative learning. Interaction is based on exchange of information, requiring members to formulate arguments or reorganise material to introduce new relationships or concepts. Through formulating ideas in their words, and receiving feedback and evaluation from peers, members' knowledge, thinking skills and meanings are socially constructed (Harasim et.al. 1995). Active participation strengthens learning. A learner is regarded as present online only when he or she makes a comment. "Lurkers", that is those who read but do not comment, are not regarded as part of the learning environment.

Online education allows for both place-independent and timeindependent learning and collaborations. Asynchronous communication allows users to participate at a time and at a pace convenient to them and appropriate to the application. Participants can respond immediately or they may elect to respond after taking time to reflect and compose a response thoughtfully. The quality of participation can be greatly improved online.

Kaye (1992) claims that although the para-linguistic cues of face-to-face or telephone communication are missing, the medium does offer greater communication richness than the more familiar forms of textual communication used by groups. The cumulative record of message contributions provide a greater potential for reflective and thoughtful analysis and review of earlier contributions than would participation in face-to-face seminars. The interaction develops written communication skills, enhances in-depth processing and recall of course material, and prepares students for examinations demanding written responses. However, the lack of control over turn-taking, and the frequent development of multiple threads of discussion within the same message space, can provide obstacles to effective collaboration.

Most advantages of computer conferencing have disadvantages bound up with them. However, the democratic and equalising tendency of computer 
conferencing has been noted in the literature. Mason (1994) claims access is the essence of the medium, not status. CMC and other technologies have the potential for blurring the traditional distinctions between the classroom-based and distance education provision as well as enriching the distance education experience. In addition to creating an active, collaborative environment, communities among users may develop which can be both personally and educationally enriching.

\section{The Deakin Project}

Deakin University has, over a number of years, committed resources to the development of communication technologies in all aspects of teaching and learning (for background details on the development of CMC at Deakin University see Goodwin, Graham \& Scarborough, 1999). To capitalise on the benefits of CMC, in 1995 a suite of networked software packages was introduced which enables students and teachers to communicate interactively, led by electronic bulletin boards, electronic mail, small group computer conferencing and also providing access to online resources.

In 1996 it was decided to adopt the use of CMC in developing collaborative learning in both the teaching and assessment of the first year microeconomics and macroeconomics units to distance education students. Staff faced the challenge of adapting the undergraduate units to maximise the potential benefits of CMC and create a richer learning experience to address some of the difficulties students traditionally experience with first year economics. Each off-campus student was provided with the choice of learning using the traditional method, involving printed course notes, phone contact with staff and assessment via assignments (which are returned with comments) and a final exam; or learning using the FirstClass conferencing facility incorporating the above, but also providing the student with computer access to both other students and staff with part of the formal assessment incorporating the online collaborative environment.

FirstClass is a computer conference system from SoftArc Inc, providing a graphical user interface makes it easy to send and receive electronic mail, share files, and use electronic conferencing to exchange ideas and participate in online chats. FirstClass enables students to communicate both asynchronously and synchronously in a number of forms. For example there are distinct areas for functions such as social chatting, second hand book sales in addition to teaching areas for the various units studied. 
This paper reports on the use of two teaching areas, the bulletin board for the first year macroeconomic unit and the tutorial group platforms. The bulletin board was an open forum accessible to all enrolled students and staff involved in the unit. This forum was used by staff to disseminate information relating to the unit content, assignments and assessments and for general questions from students to both staff and other students. The tutorial group platforms resembled on-campus tutorials in that access was restricted to the members of the tutorial group and the tutor assigned to the group.

\section{The tutorial program}

Students were allocated to tutorial groups of six as they logged on to the system at the beginning of semester. This meant that the group members were identified independently of factors such as geographic situation, but did seem to result in the more highly motivated students being grouped together which proved to be a successful strategy.

Five tutorial exercises were set, each consisting of six questions to be completed over a two week period. To promote collaborative learning, each student was instructed to take responsibility for one question and after researching the topic, post his/her answer on the group tutorial board. Comments and discussion were encouraged to promote interdependence and increase the level of support and motivation experienced by students. One member of the group was required to collate final answers and submit the group's exercise to the tutor. Group ownership of the exercise was encouraged by the fact that each member of the group shared the same mark for the exercise yet individual accountability was also present, since students ultimately held responsibility for the final format of their assigned question. The key elements identified in the literature as promoting collaborative learning, namely interdependence, individual accountability, interpersonal and group skills and group processing were encouraged.

The questions set in the exercises resembled as closely as possible the work being completed by on-campus students in tutorial groups. As all students complete the same final exam, equity in terms of the material completed was an objective.

The tutor's role was complementary to both the group and the individual student's work. The syndicate group became the focus of learning with the 
tutor, no longer at the centre of the learning process, initiating active group approaches to learning and assisting individuals in coming to terms with the theory. This decreased both the isolation and the response time many off-campus students experience when difficulties are encountered.

\section{Evaluation}

Evaluating the use of computer conferencing in a collaborative learning activity involves the analysis of many interacting variables, some of which can be measured using quantitative techniques, while others require qualitative analysis to enable a more comprehensive evaluation. Evaluation in this study combines both approaches.

\section{Methodology}

Analysis is based on surveys conducted over a two year period, 1996-97. In the first year, two questionnaires were administered to all off-campus students in first year undergraduate macroeconomics in second semester (see Appendix A for copies of questionnaires). The first was early in the semester with the aims of gaining background information and testing the attitudes of students to collaborative learning, CMC and economics in general. It was based on a study by Kerr \& Hiltz (1982) which identified categories and characteristics of individuals and groups that influence the acceptance and use of a computer conferencing system.

A follow-up questionnaire, given to those who returned the first, was undertaken near the completion of the semester to determine any change in attitude and the degree of satisfaction with the course and its delivery. In the second year, only one questionnaire was administered to all off campus students, combining questions for background information and questions directly on the study program delivered.

Table 1 illustrates the number of students participating in each survey. In the 1996 survey, eighty-three of the 206 first questionnaires were returned giving a response rate of $40 \%$. The second questionnaire, given to the 83 respondents, had a response rate of $33.7 \%$, with only $21.4 \%$ of the respondents participating in the online program. In 1997, the response rate overall was slightly less, with one third of the respondents participating in the online program. 
Interviews with staff involved in the unit and the Faculty CMC Coordinator were also undertaken. The material for this project is therefore drawn from student surveys, observation, staff interviews, and informal feedback through email, conferencing messages, and telephone conversations with students.

Table 1: Number of respondents to final questionnaire

\begin{tabular}{cccc} 
Year & Total & Using CMC & Not Using CMC \\
\hline 1996 & 28 & 6 & 22 \\
1997 & 24 & 8 & 16 \\
\hline
\end{tabular}

\section{Limitations}

The study is subject to a number of limitations. Firstly, giving students a choice may introduce some bias into results. Students opting for the method incorporating electronic delivery, may well be the more highly motivated, willing to accept a challenge student who will perform well regardless of the mode of study adopted.

Secondly, the number of students participating in the on-line program over both years was below expectations. This was a reflection of factors beyond the control of the economic staff such as technical difficulties faced by students including lack of access to and confidence with the technology.

In addition, measuring outcomes based on grades is limited as it fails to recognise the intrinsic values that may be gained from collaborative learning. Further a myriad of factors can influence student outcomes and controlling for each individual factor is not possible.

\section{Survey results}

Analysis of the survey conducted after the first year of the program, examining age and sex variables with overall performance, did not show any strong correlation. However, the performance of students using CMC improved greatly in the second year of the program with $60 \%$ of students involved in the on-line tutorial program receiving a final grade for the unit of distinction or higher. This may reflect the type of students who elected to be part of the program, as discussed in our limitations, however, even if 
this is the case, it suggests that an appropriate distance learning teaching strategy was provided for these students. Attitude towards economics did correlate with the grade achieved. Those holding a positive attitude, irrespective of study mode adopted, attained good grades.

Analysis of the usefulness of CMC, summarised in Table 2, highlighted the open access to the tutor/lecturer as the greatest potential benefit of the program. Prior to commencing the tutorial program in 1996, 61\% of online respondents thought that easier access to staff and other students would be beneficial and improve their understanding of the material. At the end of the semester, $83 \%$ of respondents involved in the tutorial program claimed this a major benefit. Two-thirds of the respondents thought the feedback from group members and generally being part of a group was beneficial but only one third would argue strongly in favour of this aspect. Half the students were positive about the program overall, while about the same number focused on the extra work created.

Table 2: Useful features of CMC to participants

\begin{tabular}{lcc} 
& 1996 & 1997 \\
\hline Access to Lecturer and Students & $83 \%$ & $87.5 \%$ \\
Group Membership & $67 \%$ & $62.5 \%$ \\
Program Overall & $50 \%$ & $75 \%$ \\
\hline
\end{tabular}

For those respondents engaged in CMC in the second year of the program, all felt part of a group and for approximately two-thirds, $62.5 \%$, a social bond developed. For $87.5 \%$ easier access to staff and other students was important and helpful with their study, viewing the feedback received from the group as useful, although it did not necessarily mean that students kept up to date with their work. Three quarters of the respondents did not feel their workload had been increased, nor their flexibility reduced. The overall benefits of the program outweighed the costs for all participants.

For those respondents not adopting CMC in their mode of study in 1996, $40 \%$ felt it would be of great benefit in terms of contact with staff and students and also to facilitate their understanding of the economic content of the unit. Many however were undecided but only $7.3 \%$ indicated it would not be of any advantage. In the second year of the program, $94 \%$ of respondents not adopting CMC in their mode of study felt that access to a group of students would have been of assistance in their study but that 
this would have increased the workload for $81 \%$ and decreased the flexibility for $93 \%$. Overall $81 \%$ of respondents not adopting CMC were satisfied studying as an off campus student, although almost one third did admit to not keeping up to date with their studies.

\section{Qualitative aspects}

Feedback from staff and students has highlighted the following factors as influencing the implementation of CMC:

\section{Isolation}

For those students connected electronically, access to staff and other students was perceived to be the greatest benefit.

I find writing out queries and receiving written answers preferable to phoning staff.

Participating fully in the tutorial exercises also enhanced many students' understanding of the topic. The ability to communicate with other students broke the isolation so often felt when studying off-campus.

Four of us were chatting simultaneously last night, and as we reside in different parts of the state and interstate, this must say something positive about the benefits of CMC.

Some respondents did admit they would have liked the ability to "chat" with other students and/or staff if they could do this without increasing their work load or losing their flexibility. This however would not involve the collaboration the system is trying to capture and thus is not supported as an alternative in this paper. One other respondent claimed that although it was a good idea to keep students on track and dedicate the correct amount of time to each topic, it would have been difficult to keep up.

\section{Access}

The greatest problem students faced was the difficulty experienced in accessing the system particularly in the initial year. Of the respondents using the system, $25 \%$ saw this as the major disadvantage associated with the program.

....system great benefit to off-campus students but access sometimes impossible.

Too much time was taken up trying to log on to the system. 
This problem was addressed somewhat in the second year with students being encouraged to use external Internet service providers, although technical difficulties remained a handicap for some.

\section{Flexibility}

The need to keep up to date with the fortnightly tutorial exercises greatly reduced the flexibility many students expect from distance education. The off-campus mode of study may be a conscious selection to enable the student to work at his or her own pace and to work independently of others. On the other hand, some students lack the self discipline to work without the pressures of time and place. The asynchronous feature allows the learner more time to think about his/her contribution but by reducing the pressure to respond, it is easier for the student to drop out of the group. This did occur with some of the participants blaming difficulty in accessing the system while for others the combination of study, work and family commitments proved too much.

\section{Cost}

The uncertainty of the system particularly given the high costs involved in getting established was also an important consideration for many. In 1996, $29 \%$ claimed costs, either in terms of equipment or telephone charges, as the reason for non participation. The uncertainty of the possible benefits to be derived against the high costs was the deciding factor.

Group learning and group participation, whether online or face-to-face, are not automatic learning styles and while some groups worked very well and developed strong collaborative skills, others struggled. One participant in the tutorial program felt that the $\$ 65.00$ she spent on telephone calls over the semester to access the system was not excessive but she was disappointed with the participation and contribution of the other members of the group.

\section{Course content}

The most challenging issue is adapting of course content and pedagogy to encompass the use of CMC and capitalise on the potential benefits of collaborative learning. This has to be treated as an evolutionary process which is not fully achievable in one or two semesters. Limitations with the text based nature of computer conferencing constrain many of the activities associated with economic learning but the problem is not likely to remain for long. In addition the text formatting is very time consuming when collating answers and needs to be made simpler to avoid students having to put in so much time in the future. 
The system also allows for the provision of up to date material and for distance education students this is an exciting development. Previously, printed materials required a lead time of at least six months. Now current articles can be scanned and posted to a bulletin board for discussion or links to appropriate web addresses incorporated at any time.

\section{Workload}

The issue of the workload involved with catering for the varied needs of each group of students has also arisen for staff, particularly during the transition stage when not all distance students are on-line. This has increased the management and co-ordination role of the unit with, for example, groups of students having part of their assessment in different forms. As a consequence, equity has also become a consideration in the setting of varied assessment.

The positive aspect for staff is the easier access and interaction with a larger number of students. The asynchronous feature allows individual students to be given assistance without detracting from the group activity. This was particularly useful around assignment time when some students had more questions and needed more clarification than others. Assignment work was a separate task to the group work completed through CMC.

CMC also provides time flexibility for staff. Most staff told students at the beginning of the semester when they would log-on to the system and the response rate to queries that they could expect. However, the nature of the discourse does allow the teacher time for considered responses which has probably improved the quality of the response. The downside to this experienced by many staff is the lack of typing skills and the frustration at having to type every interaction with these students.

Staff have also experienced a loss of control to the extent that technological problems have interfered with course delivery and the submission of assessment yet these difficulties are beyond the staff member's control.

\section{Professional development}

The professional development provided by the university with respect to the introduction of CMC has been haphazard and staff in economics have met informally but frequently to discuss issues as they arise. For example, the handling of the problem of lurkers, the timing of intervention in group discussion, and the size and formation of groups have been debated. These problems have been greatly helped by the appointment of a CMC Coordinator for the Faculty who has been based on the Warrnambool 
campus. Staff have found the informal "corridor discussions" invaluable. Formal training has now been established in the Faculty and this should improve staff's understanding and appreciation of computer mediated communication and its application to the collaborative learning process.

\section{Conclusion}

The development of CMC presents a challenging new stage in the provision of off campus material. Collaborative learning can be promoted as an outcome from using CMC. Much development in terms of group dynamics and presenting challenging material is still necessary, and although pioneering new fields is difficult for both staff and students, the potential in using CMC is felt to be unlimited. CMC is more than many other on-line developments, such as teaching on the world-wide web. The emphasis here is on interaction - group interaction - and learning as a result of the interaction. The task ahead is not easy - but when is a good educationally sound teaching project likely to be? The challenge is there it is up to teachers and students to take it up.

\section{Acknowledgements}

The authors would like to thank fellow members of the School of Economics, Warrnambool campus, and Dr. R. Carr, School of Management Information Systems, for their helpful comments and assistance.

\section{Bibliography}

Bates, A.W. (1995). Technology, Open Learning and Distance Education, London: Routledge.

Biggs, J.B. and Moore, P.J. (1994). The Process of Learning, Prentice Hall, Sydney, Australia.

Candy, P.C., Crebert, G. and O'Leary, J. (1994). Developing Lifelong Learners through Undergraduate Education, Commissioned Report, National Board of Employment, Education and Training, No 28, Australian Government Publishing Service, Canberra.

Cohen E.G. (1984). Talking and working together: Status, interaction and learning. In Peterson P.L., Wilkinson L.C. \& Hallinan M. (eds), The Social Context of Instruction, Academic Press, New York.

Coombs N. (1993). CMC: The Medium and the Message. Rochester Institute of Technology, Electronic Journal of Communication, Vol 3, No 2. 
Goodwin, C., Graham, M., and Scarborough, H. (1999). Implementing computer mediated communication in an undergraduate course: A practical experience. Journal of Asynchronous Learning Networks, (JALN) http: / / www.aln.org/alnweb/journal/jaln.htm, forthcoming.

Harasim L.(1990). Online Education: An Environment for Collaboration and Intellectual Amplification. In Harasim, L.(ed.), Online Education, Perspectives on a New Environment, Praeger, New York.

Harasim L. (1991). Teaching by Computer Conferencing. In Miller, A.J. (ed), Applications of Computer Conferencing to Teacher Education and Human Resource Development. Proceedings from an International Symposium on Computer Conferencing at the Ohio State University, Colombus, Ohio, June.

Harasim, L., Hiltz, S.R., Teles, L. and Turoff, M. (1995). Learning Networks A Field Guide to Teaching and Learning Online, The MIT Press, Cambridge.

Kaye, A.R. (1992). Learning Together Apart. In Kaye, A.R. (ed), Collaborative Learning Through Computer Conferencing, The Najaden Papers, Springer-Verlag, New York.

Kaye, A. (1989). Computer-Mediated Communication and Distance Education. In Mason, R. \& Kaye, A. (ed), Mindweave: Computer-Mediated Communication and Distance Education, Pergamon, Oxford.

Kerr, E. and Hiltz, S.R. (1982), Computer-Mediated Communication Systems: Status and Evaluation, Academic Press, New York.

Kimber, D. (1996). Collaborative Learning in Management Education: Issues, benefits, problems and solutions: A literature review. ultiBASE.

Kiesler, S. (1992). Talking, Teaching and Learning in Network Groups: Lessons from Research. In Kaye, A.R. (ed), Collaborative Learning Through Computer Conferencing, The Najaden Papers, Springer-Verlag, New York.

Laurillard, D. (1993). Rethinking University Teaching: A Framework for the Effective Use of Educational Technology. Routledge, London

Mason, R. (1994). Using Communications Media in Open and Flexible Learning. Open and Distance Learning Series, Kogan Page, London.

Mason, R. and Kaye, T. (1990), Towards a New Paradigm for Distance Education. In Harasim L.(ed.), Online Education, Perspectives on a New Environment, Praeger, New York.

Moore, M.G. (1991). Computer Conferencing in the Context of Theory and Practice of Distance Education. In Miller, A.J. (ed), Applications of Computer Conferencing to Teacher Education and Human resource Development. Proceedings from an International Symposium on Computer Conferencing at the Ohio State University, Colombus, Ohio, June.

Morris, R. and Hayes, C. (1997). Small Group Work: Are group assignments a legitimate form of assessment? In Pospisil, R. and Willcoxson, L. (eds), Learning 
Through Teaching, Proceedings of the 6th Annual Teaching Learning Forum, Murdoch University, Perth, pp229-233.

http: / / ctl.curtin.edu.au/ events / conferences / tlf/tlf1997/ morris.html

Soper, J.C. and Lynn, M.P. (1994). Should we mandate the teaching of economics? The Journal Of Private Enterprise, 10(1, Summer), 65-77.

Torres, R.M., Budk,e W., Loyd, M., McCaslin N.L. and Miller, A.J. (1991).

Examining Computer Conferencing as a Technique for Enhancing Personnel Development Activities. In Miller A.J. (ed), Applications of Computer Conferencing to Teacher Education and Human Resource Development. Proceedings from an International Symposium on Computer Conferencing at the Ohio State University, Colombus, Ohio, June.

Waggoner, M. (1992). A case study approach to evaluation of computer conferencing. In Kaye, A.R. (ed), Collaborative Learning Through Computer Conferencing, The Najaden Papers, Springer-Verlag, New York

Wells, R. (1993). Computer-Mediated Communication for Distance Education: An International Review of Design, Teaching, and Institutional Issues, Research Mongraphs No.6, American Center for the Study of Distance Education, College of Education, The Pennsylvania State University.

Watts, M. and Lynch, G.J. (1989). The Principles Course Revisited. American Economic Review: Proceedings, 79(May), 236-241.

\section{Appendix A}

\section{Background Questionnaire}

This questionnaire is divided into three sections please answer Section A and chose either Section B or C.

\section{Section A: All participants to answer}

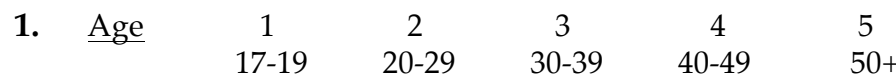

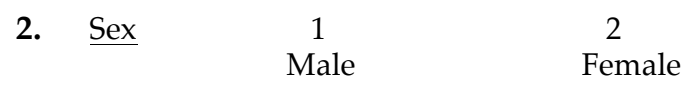

3. Which one of these groups best describes the people living in your household.

$\begin{array}{ll}\text { Single } & 1 \\ \text { Couple (no children) } & 2 \\ \text { Family (children under 15 years) } & 3 \\ \text { Family (Children over 15 years) } & 4 \\ \text { Couple (children not at home) } & 5\end{array}$


4. Which of the following groups best describes your occupation

Professional

Management Support $\quad 2$

Trade 3

Home Duties 4

Full time student 5

5. Which of the following groups best describes your location.

$\begin{array}{ll}\text { Capital City } & 1 \\ \text { Provincial City (more than 20,000 people) } & 2 \\ \text { Country Town } & 3 \\ \text { Rural } & 4 \\ \text { Overseas } & 5\end{array}$

6. Education prior to enrolling at Deakin University

$\begin{array}{ll}\text { Secondary } & 1 \\ \text { TAFE } & 2 \\ \text { Other Post Secondary Diploma } & 3 \\ \text { Undergraduate Degree } & 4 \\ \text { Other } & 5\end{array}$

7. Year of Enrolment at Deakin University

$\begin{array}{ll}1996 & 1 \\ 1995 & 2 \\ 1994 & 3 \\ 1993 & 4 \\ \text { Pre } 1993 & 5\end{array}$

8. How Many Subjects are you studying this semester?

9. How Many Subjects did you Study last Semester?

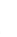

4

10. What were your Grades in Subject 1 last semester? Please list the number $N=1, P=2, C=3, D=4, H D=5$

11. What were your Grades in Subject 2 last semester? Please list the number $\mathrm{N}=1, \mathrm{P}=2, \mathrm{C}=3, \mathrm{D}=4, \mathrm{HD}=5$

12. What were your Grades in Subject 3 last semester? Please list the number $\mathrm{N}=1, \mathrm{P}=2, \mathrm{C}=3, \mathrm{D}=4, \mathrm{HD}=5$

13. What were your Grades in Subject 4 last semester? Please list the number $\mathrm{N}=1, \mathrm{P}=2, \mathrm{C}=3, \mathrm{D}=4, \mathrm{HD}=5$ 
Section B: Answer if your are using First Class conferencing in MEE102 (If you are not using First Class Conferencing in MEE 102 please go to Section C)

14. What other subjects are you studying using the Conferencing System?

$\begin{array}{ll}\text { MAA102 Accounting } & 1 \\ \text { MMM 132 Management } & 2 \\ \text { MSQ 171 Business Statistics } & 3 \\ \text { None of the above } & 4\end{array}$

15. Do you know anyone outside your group doing MEE102?

$\begin{array}{ll}\text { Yes } & 1 \\ \text { No } & 2\end{array}$

16. How many times do you use a computer each week

$\begin{array}{ll}\text { Never } & 1 \\ 1-5 \text { times } & 2 \\ 6-10 \text { times } & 3 \\ \text { More than } 10 \text { times } & 4\end{array}$

17. Rank the following statement

"I have a working knowledge of the basic programs on my computer"

$\begin{array}{ccccc}1 & 2 & 3 & 4 & 5 \\ \text { Strongly } & \text { Disagree } & \text { Undecided } & \text { Agree } & \text { Strongly } \\ \text { Disagree } & & & \text { Agree }\end{array}$

18. In order to access Deakin Interchange have you; purchased your own computer and modem 1 used a computer at work 2 used a friend's computer 3 other (please specify) 4

19. If you purchased a computer what were your setting up expenses?

$\begin{array}{ll}\text { Less than } \$ 1,000 & 1 \\ \$ 1000-1999 & 2 \\ \$ 2000-3999 & 3 \\ \$ 4000-5999 & 4 \\ \text { Greater than } \$ 5000 & 5\end{array}$

20. Did you have problems accessing First Class for MEE 102? Yes

No

If YES briefly state why. 
21. If YES to Q.20 how much lapsed before the problem was sorted out.

$\begin{array}{ll}\text { Less than } 1 \text { day } & 1 \\ 1-7 \text { Days } & 2 \\ \text { More than } 1 \text { week } & 3 \\ \text { Still not resolved } & 4\end{array}$

Rank your answers to the following questions on a scale of $\mathbf{1}$ to

$\begin{array}{ccccc}1 & 2 & 3 & 4 & 5 \\ \text { Strongly } & \text { Disagree } & \text { Undecided } & \text { Agree } & \text { Strongly } \\ \text { Disagree } & & & & \text { Agree }\end{array}$

22. I feel confident about using Interchange in my studies.
1
2
3
4
5

23. The Faculty requirement regarding the use of Interchange in the Bachelor of Commerce is reasonable.
1
2
3
4
5

24. Being able to contact other students via computer mediated communication will be a useful facility.
1
2
3
4
5

25. Interchange will give me greater access to the teaching staff in MEE102. 2 3 4 5

26. I have a general interest in economics.

1

2

3

4

5

27. Interchange will facilitate my understanding of the economic content of MEE102.
1
2
3
4
5

28. Some student assessment based on the use of Interchange is acceptable.

1

2

3

4

5

\section{Other comments}

\section{Section C: Answer if you are not using First Class conferencing in MEE 102}

29. Do you have access to a computer

Yes

1

No

2

If NO go to Q.31 
30. How many times do you use a computer each week

$\begin{array}{ll}\text { Never } & 1 \\ 1-5 \text { times } & 2 \\ 6-10 \text { times } & 3 \\ \text { More than } 10 \text { times } & 4\end{array}$

Rank your answers to the following questions on a scale of 1 to 5

$\begin{array}{ccccc}1 & 2 & 3 & 4 & 5 \\ \text { Strongly } & \text { Disagree } & \text { Undecided } & \text { Agree } & \text { Strongly } \\ \text { Disagree } & & & & \text { Agree }\end{array}$

31. "I have a working knowledge of the basic programs on my computer"
2
3
4

1

5

32. The Faculty requirement regarding the use of Interchange in the Bachelor of Commerce is reasonable.
12
3
4
5

33. Being able to contact other students via computer mediated communication would be a useful facility. 1 2
3
4
5

34. First Class would give me greater access to the teaching staff in MEE 102.
1
2
3
$4 \quad 5$

35. I have a general interest in economics.

$\begin{array}{rrrrr}1 & 2 & 3 & 4 & 5\end{array}$

36. Interchange may have facilitated my understanding of the economic content of MEE 102.
1
2
3
4
5

37. Some student assessment based on the use of First Class is acceptable.

2

3

4

5

38. Why did you elect not to use Interchange in your study of MEE102?

\section{OTHER COMMENTS}

Thank you for participating 


\section{Questionnaire 2 1996: Online participants}

1. How many hours a week did you spend using First Class for MEE 102

1. less than 5 hours

2. 6-8 hours

3. 9 -10 hours

4. More than 10 hours

2. How many hours a week did you spend using First Class other than for MEE102

1. less than 5 hours

2. 6-8 hours

3. 9-10 hours

4. More than 10 hours

3. How many tutorial exercises did you contribute to in MEE 102
1. None
2. 1 to 2
3. 3 to 4
4. All

4. How many discussions, on average, did you have with your MEE102 tutorial group each week?
1 none
2. one
3. two to three
4. four to five
5. more than five

Rank your answers to the following questions on a scale of 1 to 5

$\begin{array}{ccccc}1 & 2 & 3 & 4 & 5 \\ \text { Strongly } & \text { Disagree } & \text { Undecided } & \text { Agree } & \text { Strongly } \\ \text { Disagree } & & & & \text { Agree }\end{array}$

5. I was happy about the tutorial group to which I was assigned.
1
2
5

6. I was keen to log on and interested to read messages left by other members of my tutorial group.
1
2
3
4
5

7. I missed out if I didn't log on regularly.
1
2
3
4
5

8. I had a negative approach to group work before I began using the First Class system.
1
2
34
5

9. I found my attitude to group work changed after using the First Class system.
1
2
3
4
5

10. My confidence to contribute to the group increased over time.

1

2

3

4 
11. I could make suggestions to my tutorial group
1
23
34

12. I was happy to wait for someone else to initiate discussion
1
2
4

13. I felt part of my tutorial group

2

4

14. I developed a social bond with other members of my tutorial group

2

4

5

15. I received positive feedback from my tutorial group

$\begin{array}{llll}1 & 2 & 3 & 4\end{array}$

16. I found economics interesting after participating in the First Class tutorial program.

$\begin{array}{lrlll}1 & 2 & 3 & 4 & 5\end{array}$

17. The tutorial program in First Class had a positive impact on my ability to learn and understand economics.
2
4

18. The fortnightly tutorial program encouraged me to keep up to date with my study in MEE 102
1
2
3
4

19. The fortnightly tutorial program unnecessarily increased my workload in MEE 102.
4

20. The electronic tutorial program encroached on the amount of time I had to spend on studying other aspects of MEE 102
1
2
3
4

21. I found First Class encouraged group learning

$\begin{array}{lllll}1 & 2 & 3 & 4 & 5\end{array}$

22. First Class increased my confidence in the use of computer mediated communication
1
4

23. My experience with MEE 102 would encourage me to study economics at second and third year levels
1
2
4
5

24. My experience with First Class would encourage me to study other economic units using this facility
1
2
3
4
5

25. I found First Class gave me greater access to staff members.

23

34 
26. My tutor gave regular feedback on my work.

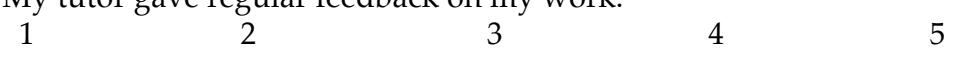

27. I could ask my tutor questions

$\begin{array}{lllll}1 & 2 & 3 & 4 & 5\end{array}$

28. My tutor encouraged participation amongst group members
1
23
4
5

29. I have found it difficult to log on when I wanted to access I tutorial group. 2 4

30. Problems with logging on have impacted on my study time on a regular basis 1 2 3 4 5

31. I have had recurring technical problems with the use of First Class
1
2
3
4
5

32. The service offered by Information Technology Services (ITS) was satisfactory.

12

3

4

5

33. What was your estimated running cost of using First Class this semester

1. less than $\$ 50$

2. \$51- $\$ 100$

3. \$101-150

4. $\$ 151-\$ 200$

5. More than $\$ 200$

34. How many times did you have to contact ITS with technical problems this semester
1. None
2. 1-5 times
3. 6-10 times
4. 11-20 times
5. More than 20 times

\section{Comments}

Thank you for participating 


\section{Questionnaire 2 1996: Non participants}

1. How many hours a week did you spend studying MEE102

1. less than 5 hours

2. 6-8 hours

3. $9-10$ hours

4. More than 10 hours

2. Did you have contact with other students studying MEE 102

1. Yes

2. No

3. If YES to 2 how frequent was this contact?

1. 1-2 times during the semester

2. 3-4 times during the semester

3. Regularly each week

4. How frequently did you contact your lecturer by telephone or conventional mail?

1. Never

2. Once

3. 2 - 3 times

4. More than 3 times

5. How many assignments did you submit?

$\begin{array}{ll}\text { 1. } & \text { None } \\ \text { 3. } & 1 \\ \text { 4. } & 2 \\ & 3\end{array}$

6. How many self review exercises from the MEE 102 study guide did you complete?

1. None

2. 1 to 3

3. $4-8$

4. $9-12$

7. Did you use study materials other than those prescribed for MEE 102?

1. Yes

2. No

Rank your answers to the following questions on a scale of $\mathbf{1}$ to 5

$\begin{array}{ccccc}1 & 2 & 3 & 4 & 5 \\ \text { Strongly } & \text { Disagree } & \text { Undecided } & \text { Agree } & \text { Strongly } \\ \text { Disagree } & & & & \text { Agree }\end{array}$

8. I found the economic content of MEE 102 interesting.
1
2
3
4
5

9. My experience with MEE 102 would encourage me to undertake further studies in economics. 
10. I received adequate feedback on my assignments

11. I could ring my lecturer and seek help if required

$\begin{array}{llllll}1 & 2 & 3 & 4 & 5\end{array}$

12. I found it difficult to gain access to teaching staff members
1
2

13. I was happy studying MEE 102 on my own

$\begin{array}{lllll}1 & 2 & 3 & 4 & 5\end{array}$

14. I preferred working at my own pace

$\begin{array}{lllll}1 & 2 & 3 & 4 & 5\end{array}$

15. I found it difficult to keep up to date with my studies
1
2
3
4
5

16. I found it difficult not having other student to discuss problems with
1
2
3
4 5

17. Access to a group of students studying MEE 102 would have been of assistance in my study
1
2
3
4

5

18. I would have liked to have participated in group work
1
2
3
4

19. A fortnightly tutorial program would have helped me keep up to date in MEE 102
1
2
3
4
5

20. A fortnightly tutorial program would have unnecessarily increased the workload in this subject
1
2
3
4
5

\section{Comments}

Thank you for participating 


\section{Questionnaire for online participants}

Please indicate the most appropriate response in the space provided.
1. Age $17-19$

$22-29$
30-39
40-49
$55+$
2. Sex Male

23
4

5

1
Answer........

3. Which of the following groups best describes your occupation

Professional

1

Management Support

Trade

Home Duties

Full time student

4

5

Answer........

4. Which of the following groups best describes your location.

$\begin{array}{ll}\text { Capital City } & 1 \\ \text { Provincial City }(>20,000 \text { people }) & 2 \\ \text { Country Town } & 3 \\ \text { Rural } & 4 \\ \text { Overseas } & 5\end{array}$

Overseas

5

Answer..........

5. Education prior to enrolling at Deakin University

$\begin{array}{ll}\text { Secondary } & 1 \\ \text { TAFE } & 2 \\ \text { Other Post Secondary Diploma } & 3 \\ \text { Undergraduate Degree } & 4 \\ \text { Other } & 5\end{array}$

6. How many hours a week did you spend studying MEE102?

Answer...........

$\begin{array}{ll}\text { Less than } 5 \text { hours } & 1 \\ 6-8 \text { hours } & 2 \\ 9-10 \text { hours } & 3 \\ \text { More than } 10 \text { hours } & 4\end{array}$
2
More than 10 hours
4
Answer............

7. Did you value having contact with other students studying MEE 102?

Yes

Answer...........

8. If Yes to Q7, was this contact with other students using (mark more than one if appropriate)

$\begin{array}{ll}\text { Only Firstclass } & 1 \\ \text { Email } & 2 \\ \text { Telephone } & 3 \\ \text { Personal } & 4\end{array}$

Rank your answers to the following questions on a scale of 1 to 5

$\begin{array}{ccccc}1 & 2 & 3 & 4 & 5 \\ \text { Strongly } & \text { Disagree } & \text { Undecided } & \text { Agree } & \text { Strongly } \\ \text { Disagree } & & & & \text { Agree }\end{array}$

9. I have a general interest in economics
1
2
3

4 
10. I found the economic content of MEE 102 interesting.

$\begin{array}{llll}1 & 2 & 3 & 4\end{array}$

11. My experience with MEE 102 would encourage me to undertake further studies in economics.
1
2
3
4
5

12. Access to teaching staff members was adequate

$\begin{array}{llll}1 & 2 & 3 & 4\end{array}$

4

13. The feedback received from teaching staff enhanced my learning
1
2
34
5

14. I was satisfied studying MEE 102 as an off-campus student
1
23
4

15. I kept up to date with my studies
1
2
$3-4$
5

16. Access to a group of students studying MEE 102 was of assistance in my study

2

3

4

5

17. The fortnightly tutorial program unnecessarily increased the workload in this subject
1
2
3
4

18. The fortnightly tutorial program reduced the flexibility I expect from off-campus study
1
2
4

19. I felt part of my tutorial group
1
2
3
4
5

20. I developed a social bond with other members of my tutorial group
1
2
3
4
5

21. The feedback received from my tutorial group enhanced my learning
1
2
3
4

\section{5}

22. I found economics interesting after participating in the First Class tutorial program
1
23
4
5

23. The tutorial program in First Class had a positive impact on my ability to learn and understand economics.

$\begin{array}{lllll}1 & 2 & 3 & 4\end{array}$

24. The fortnightly tutorial program encouraged me to keep up to date with my study in MEE 102
12
23
34
5

25. The benefits gained from using First Class justified the costs incurred 2

3

4

5 
Further Comments

Thank you for participating

\section{Questionnaire for non-participants}

Please circle the appropriate response.

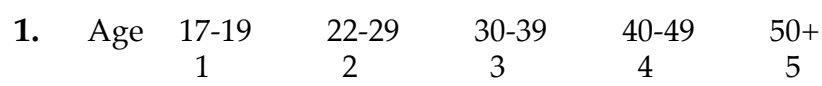

2. Sex Male 1

Female 2

3. Which of the following groups best describes your occupation?

Professional

Management Support

Trade

1

3

Home Duties

Full time student 5

4. Which of the following groups best describes your location?

$\begin{array}{ll}\text { Capital City } & 1 \\ \text { Provincial City (more than 20,000 people) } & 2 \\ \text { Country Town } & 3 \\ \text { Rural } & 4 \\ \text { Overseas } & 5\end{array}$

5. Education prior to enrolling at Deakin University Secondary 1

TAFE 2

Other Post Secondary Diploma 3

Undergraduate Degree 4

Other 5

6. How many hours a week did you spend studying MEE102?

Less than 5 hours 1

6-8 hours 2

9-10 hours 3

More than 10 hours 4

7. Did you have contact with other students studying MEE 102

$\begin{array}{ll}\text { Yes } & 1 \\ \text { No } & 2\end{array}$

8. If YES to Q.7, how frequent was this contact?

$\begin{array}{ll}1-2 \text { times during the semester } & 1 \\ 3-4 \text { times during the semester } & 2\end{array}$

$\begin{array}{ll}3-4 \text { times during the semester } & 2 \\ \text { Regularly each week } & 3\end{array}$ 


\section{Rank your answers to the following questions on a scale of $\mathbf{1}$ to 5

$\begin{array}{ccccc}1 & 2 & 3 & 4 & 5 \\ \text { Strongly } & \text { Disagree } & \text { Undecided } & \text { Agree } & \text { Strongly } \\ \text { Disagree } & & & & \text { Agree }\end{array}$

9. I have a general interest in economics
2
3
4
5

10. I found the economic content of MEE 102 interesting.
1
2
3
4
5

11. My experience with MEE 102 would encourage me to undertake further studies in economics.
1
2
3
4
5

12. Access to teaching staff members was adequate
1
23
4
5

13. The feedback received from teaching staff enhanced my learning
1
2
3
4
5

14. I was satisfied studying MEE 102 as an off-campus student

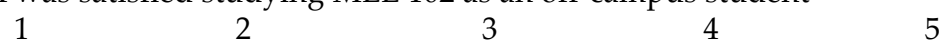

15. I kept up to date with my studies
1
2
34
5

16. Access to a group of students studying MEE 102 would have been of assistance in my study
$1 \quad 2$
3
4
5

17. A fortnightly tutorial program would have unnecessarily increased the workload in this subject
1
2
3
4
5

18. A fortnightly tutorial program would have reduced the flexibility I expect from off-campus study
12
3
4

19. I did not connect to Deakin Interchange because

20. Any further comments

Thank you for participating 